\title{
QSARs in prooxidant mammalian cell cytotoxicity of nitroaromatic compounds: the roles of compound lipophilicity and cytochrome P-450- and DT-diaphorase-catalyzed reactions
}

\author{
Aušra Nemeikaitè-Čèniené ${ }^{1}$, \\ Jonas Šarlauskas ${ }^{2}$, \\ Violeta Jonušien $\dot{e}^{3}$, \\ Lina Misevičien $\dot{e}^{2}$, \\ Audronè Maroziené², \\ Aliaksei V. Yantsevich ${ }^{4}$, \\ Narimantas Čènas ${ }^{2 *}$ \\ ${ }^{1}$ State Research Institute Centre \\ for Innovative Medicine, \\ 5 Santariškiu Street, \\ 08406 Vilnius, Lithuania \\ ${ }^{2}$ Institute of Biochemistry of Vilnius University, \\ 7 Sauletekio Street, \\ 10257 Vilnius, Lithuania \\ ${ }^{3}$ Institute of Biosciences of Vilnius University, \\ 7 Sauletekio Street, \\ 10257 Vilnius, Lithuania \\ ${ }^{4}$ Institute of Bioorganic Chemistry, \\ NAS of Belarus, \\ Kuprevicha 5/2, \\ BY-220072 Minsk, Belarus
}

Frequently, the aerobic mammalian cell cytotoxicity of nitroaromatic compounds $\left(\mathrm{ArNO}_{2}\right)$ increases with their single-electron reduction potential $\left(E_{7}^{1}\right)$, thus reflecting the relationship between their enzymatic single-electron reduction rate and $E_{7}^{1}$. This shows that the main factor of $\mathrm{ArNO}_{2}$ cytotoxicity is redox cycling and oxidative stress. In this work, we found that the reactivity of a series of nitrobenzenes, nitrofurans and nitrothiophenes towards single-electron transferring NADPH:cytochrome P-450 reductase and adrenodoxin reductase/adrenodoxin increases with their $E^{1}$. However, their cytotoxicity in mouse hepatoma MH22a and human colon carcinoma HCT-116 cells exhibited a poorly expressed dependence on $E^{1}$. The correlations were significantly improved after the introduction of compound octanol/water distribution coefficient at pH $7.0(\log D)$ as a second variable. This shows that the lipophilicity of $\mathrm{ArNO}_{2}$ enhances their cytotoxicity. The inhibitors of cytochromes P-450, $\alpha$-naphthoflavone, isoniazid and miconazole, and an inhibitor of DT-diaphorase, dicoumarol, in most cases decreased the cytotoxicity of several randomly chosen compounds. This shows that the observed cytotoxicity vs $E_{7}^{1}$ relationships in fact reflect the superposition of several cytotoxicity mechanisms.

Keywords: nitroaromatic compounds, cytotoxicity, oxidative stress, cytochrome P-450, DT-diaphorase

\section{INTRODUCTION}

Nitroaromatic compounds $\left(\mathrm{ArNO}_{2}\right)$ such as nitrobenzenes, nitrofurans, nitrothiophenes and

\footnotetext{
* Corresponding author: Email: narimantas.cenas@bchi.vu.lt
}

nitroimidazoles are widely used as antimicrobial, antiparasitic, antifungal and anticancer agents. Besides, nitroaromatic explosives and pesticides comprise an important group of toxic environmental pollutants ([1-3], and references therein). The quantitative structure-activity relationships 
(QSARs) of their cytotoxicity enable one to characterize their action mechanisms and provide the guidelines for the design of new compounds with desired properties.

The simplest form of QSARs describing the cytotoxicity of $\mathrm{ArNO}_{2}$ under aerobic conditions is a negative dependence of $\mathrm{cL}_{50}$ (compound concentration causing $50 \%$ cell killing) on their electron-accepting potency, e.g. single-electron reduction potential, $E_{7}^{1}$. The frequently observed relationships $\Delta \log \mathrm{cL}_{50} / \Delta E_{7}^{1} \sim-10 \mathrm{~V}^{-1}$ mirror the $\log$ (rate constant) vs $E_{7}^{1}$ relationships in single-electron reduction of nitroaromatics by flavoenzymes dehydrogenases-electrontransferases, e.g. NADPH:cytochrome P-450 reductase (P-450R) 48]. It could mean that the main cytotoxicity factor is the rate of formation of free radicals of nitroaromatics $\left(\mathrm{ArNO}_{2}^{-}\right)$. Further, their reoxidation with oxygen yields superoxide $\left(\mathrm{O}_{2}^{-}\right), \mathrm{H}_{2} \mathrm{O}_{2}$ and hydroxyl radical $(\mathrm{OH})$, i.e. causes the oxidative stress [6, 9]. The presence of reactive substituents, e.g. aziridine or $\mathrm{N}, \mathrm{N}$-bis(2-chloroethyl)-amine group, may enhance the cytotoxicity of $\mathrm{ArNO}_{2}$ above the limits predictable by their $E_{7}^{1}$ [ [ ㄱ, 10].

However, the observed dependence of $\log \mathrm{cL}_{50}$ on $E_{7}^{1}$ may result from the superposition of oxidative stress and other cytotoxicity factors. The cytotoxicity of $\mathrm{ArNO}_{2}$ lacking bioreductively activated groups was modulated by the inhibitors of flavoenzyme DT-diaphorase $(\mathrm{NAD}(\mathrm{P}) \mathrm{H}$ : quinone oxidoreductase, NQO1) and cytochromes P-450 [8, 1113. NQO1 performs two(four)-electron reduction of $\mathrm{ArNO}_{2}$ into DNA-alkylating hydroxylamines $(\mathrm{ArNHOH})([14,15]$, and references therein), and cytochromes P- 450 catalyze the oxidative denitration of $\mathrm{ArNO}_{2}[16,17]$.

Besides, $\mathrm{ArNHOH}$ and amines $\left(\mathrm{ArNH}_{2}\right)$ may be formed as the reaction byproducts due to the dismutation of $\mathrm{ArNO}_{2}^{-}$or due to a limited oxygen supply. However, it is unclear how do these processes contribute to cytotoxicity vs $E_{7}^{1}$ relationships. The data on the role of lipophilicity in the aerobic cytotoxicity of $\mathrm{ArNO}_{2}$ are also equivocal [4, 5, 8, 13, 18. This points to a need of more thorough characterization of the above factors.

In this work, we demonstrated that the cytotoxicity of a series of structurally diverse nitrofurans, nitrobenzenes and nitrothiophenes in two cell lines increased with their $E_{7}^{1}$, and possessed the prooxidant character. Further, we attempted to characterize the possible contribution of compound lipophilicity and NQO1- and cytochrome P-450-catalyzed processes to their cytotoxicity.

\section{MATERIALS AND METHODS}

Recombinant rat P-450R, bovine NADPH: adrenodoxin reductase (ADR) and adrenodoxin (ADX) were prepared as described in [19], their concentrations were determined according to $\varepsilon_{456}=21.4 \mathrm{mM}^{-1} \mathrm{~cm}^{-1}, \varepsilon_{450}=11.0 \mathrm{mM}^{-1} \mathrm{~cm}^{-1}$ and $\varepsilon_{414}=10.0 \mathrm{mM}^{-1} \mathrm{~cm}^{-1}$, respectively. NQO1 was prepared from rat liver according to Prochaska [20], its concentration was determined according to $\varepsilon_{460}=11.0 \mathrm{mM}^{-1} \mathrm{~cm}^{-1}$. Nitrothiophenes $\mathbf{1 a}-\mathbf{c}$ and vinylquinoline-substituted nitrofurans $\mathbf{2 a - c}$ (Fig. 1) were synthesized as described in [21] and [22], respectively. The compound purity was characterized by IR and NMR spectrometry, melting point and elemental analysis. Other reagents were obtained from Sigma-Aldrich, and used as received.

The kinetic measurements were carried out spectrophotometrically using a PerkinElmer Lambda 25 spectrophotometer in the $0.1 \mathrm{M} \mathrm{K}$-phosphate buffer (pH 7.0) containing $1 \mathrm{mMEDTA}$ at $25^{\circ} \mathrm{C}$. The enzyme activities determined according to the rate of reduction of $50 \mu \mathrm{M}$ cytochrome $c\left(\Delta \varepsilon_{550}=20 \mathrm{mM}^{-1} \mathrm{~cm}^{-1}\right)$ at substrate concentrations indicated below were close to those reported previously [23]: $39 \mathrm{~s}^{-1}$ $(\mathrm{P}-450 \mathrm{R},[\mathrm{NADPH}]=100 \mu \mathrm{M}), 7.5 \mathrm{~s}^{-1}(\mathrm{ADR}$, $[\mathrm{ADX}]=0.5 \mu \mathrm{M},[\mathrm{NADPH}]=50 \mu \mathrm{M})$, and $1750 \mathrm{~s}^{-1}$ (NQO1, [NADPH] $=150 \mu \mathrm{M}$, [menadione $=10 \mu \mathrm{M})$. In this case, $0.01 \%$ Tween 20 and $0.25 \mathrm{mg} / \mathrm{mL}$ bovine serum albumin were added as NQO1 activators. The initial rates of enzymatic $\mathrm{NADPH}$-dependent nitroreduction were determined according to $\Delta \varepsilon_{340}=6.2 \mathrm{mM}^{-1} \mathrm{~cm}^{-1}$ after the subtraction of intrinsic NADPH oxidase activities of enzymes, $0.05 \mathrm{~s}^{-1}$ (P-450R), $0.1 \mathrm{~s}^{-1}$ (NQO1) and $0.11 \mathrm{~s}^{-1}(\mathrm{ADR}+0.5 \mu \mathrm{M}$ ADX). The stock solutions of oxidants were prepared in DMSO (dilution factor 100). The values of turnover rate, $k_{\text {cat }}$, reflecting the maximal number of moles NADPH oxidized or oxidant reduced per mole of the enzyme active centre per second, and $k_{\mathrm{cat}} / K_{\mathrm{m}}$, the bimolecular rate constant (or catalytic efficiency constant), correspond to the inverse intercepts and slopes in LineweaverBurk coordinates, [E]/v vs $1 /$ [oxidant]. These rate constants were obtained by fitting the experimental data to the parabolic expression using the SigmaPlot 
2000 (Version 11.0, Systal Software). In some experiments, the NADPH regeneration system $(20 \mu \mathrm{M}$ NADPH, $10 \mathrm{mMglucose}$-6-phosphateand $0.3 \mathrm{mg} / \mathrm{mL}$ glucose-6-phosphate dehydrogenase) was used.

Murine hepatoma MH22a cells, obtained from the Institute of Cytology of the Russian Academy of Sciences (St. Petersburg, Russia), were grown and maintained at $37^{\circ} \mathrm{C}$ in DMEM medium, supplemented with $10 \%$ fetal bovine serum and antibiotics [23]. In the cytotoxicity experiments, $3.0 \times 10^{4} / \mathrm{ml}$ cells were seeded in 5-mL flasks in the absence or in the presence of compounds, and were grown for $24 \mathrm{~h}$. The cell viability was determined by Trypan blue exclusion. In control experiments, the cell viability was 98.5-99.3\%. Human colon adenocarcinoma cells HCT-116, obtained from ATCC (Manassas, VA, USA), were grown and maintained at $37^{\circ} \mathrm{C}$ in $5 \% \mathrm{CO}_{2}$ in the RPMI 1640 DMEM medium, supplemented with $10 \%$ fetal bovine serum, $2 \mathrm{mM}$ L-glutamine and antibiotics [23]. In the cytotoxicity experiments, $1.0 \times 10^{5} / \mathrm{ml}$ cells were seeded in the absence or in the presence of compounds, and were grown for $48 \mathrm{~h}$. Their viability was determined by staining with crystal violet. Stock solutions of compounds were prepared in DMSO. Its concentration in cultivation media did not exceed $0.2 \%$ and did not affect cell viability. The experiments were conducted in triplicate. The statistical analysis was performed using Statistica (Version 4.3, Statsoft). Octanol/water distribution coefficients at $\mathrm{pH} 7.0(\log D)$ were calculated using LogD Predictor (https://chemaxon.com).

\section{RESULTS}

In this work, we used a number of nitroaromatic compounds whose $E^{1}$ varied between -0.191 and $-0.485 \mathrm{~V}$ (Table 1). The formulae of nontrivial compounds are given in Fig. 1. One may note that these compounds lack bioreductively activated or other reactive substituents. First, we studied their singleelectron reduction with $\mathrm{P}-450 \mathrm{R}$, which probably plays the most important role in redox cycling of

Table 1. Single-electron reduction potentials of nitroaromatic compounds $\left(E_{7}\right)_{7}$, their octanol/water distribution coefficients at $\mathrm{pH} 7.0$ (log $D)$, bimolecular reduction rate constants $\left(k_{\text {car }} / K_{\mathrm{m}}\right)$ by NADPH:cytochrome $\mathrm{P}-450$ reductase $(\mathrm{P}-450 \mathrm{R})$ and adrenodoxin reductase/ adrenodoxin $(\mathrm{ADR} / \mathrm{ADX})$, and their concentrations causing $50 \%$ cell death $\left(\mathrm{CL}_{50}\right)$ or $50 \%$ cell growth inhibition $\left(\mathrm{Gl}_{50}\right)$

\begin{tabular}{|c|c|c|c|c|c|c|c|}
\hline \multirow{2}{*}{ No. } & \multirow{2}{*}{ Compound } & \multirow{2}{*}{$\begin{array}{c}E^{1}, V \\
{[21,24,25]}\end{array}$} & \multirow{2}{*}{$\log D$} & \multicolumn{2}{|c|}{$k_{\mathrm{cat}} / K_{\mathrm{m}}, \mathrm{M}^{-1} \mathrm{~s}^{-1}$} & \multicolumn{2}{|c|}{$\mathrm{CL}_{50}\left(\mathrm{GI}_{50}{ }^{\mathrm{a}}\right), \mu \mathrm{M}$} \\
\hline & & & & P-450R & ADR/ADX & MH22a & HCT-116 \\
\hline 1. & Nitrobenzene & -0.485 & 1.91 & $6.8 \pm 0.8 \times 10^{2}$ & $3.4 \pm 0.2 \times 10^{3}$ & $1800 \pm 200$ & $>5000$ \\
\hline 2. & 4-Nitrobenzoic acid & -0.425 & -1.66 & $2.3 \pm 0.2 \times 10^{3}$ & $2.0 \pm 0.2 \times 10^{3}$ & $>6000$ & $>6000$ \\
\hline 3. & 2-Nitrothiophene & -0.390 & 1.86 & $1.4 \pm 0.1 \times 10^{4}$ & $4.2 \pm 0.3 \times 10^{4}$ & $341 \pm 42$ & n.d. \\
\hline 4. & 4-Nitroacetophenone & -0.355 & 1.47 & $1.7 \pm 0.2 \times 10^{4}$ & $3.2 \pm 0.3 \times 10^{4}$ & $239 \pm 19$ & $400 \pm 80$ \\
\hline 5. & 3,5-Dinitrobenzoic acid & -0.345 & -1.79 & $3.3 \pm 0.2 \times 10^{4}$ & n.d. & $910 \pm 80$ & $3000 \pm 400$ \\
\hline 6. & 1,3-Dinitrobenzene & -0.345 & 1.85 & $4.9 \pm 0.2 \times 10^{4}$ & $5.2 \pm 0.4 \times 10^{4}$ & $130 \pm 14$ & $350 \pm 50$ \\
\hline 7. & 4-Nitrobenzaldehyde & -0.325 & 1.63 & $3.3 \pm 0.2 \times 10^{4}$ & $1.7 \pm 0.3 \times 10^{5}$ & $200 \pm 15$ & $50 \pm 6.0$ \\
\hline 8. & 3,5-Dinitrobenzamide & -0.311 & 0.70 & $6.6 \pm 0.3 \times 10^{4}$ & n.d. & $130 \pm 15$ & $100 \pm 10$ \\
\hline 9. & Nitrothiophene 1a & -0.305 & 1.07 & $1.4 \pm 0.2 \times 10^{5}$ & $4.1 \pm 0.6 \times 10^{5}$ & $82 \pm 12$ & n.d. \\
\hline 10. & 1,2-Dinitrobenzene & -0.287 & 1.85 & $1.6 \pm 0.1 \times 10^{5}$ & $1.8 \pm 0.2 \times 10^{5}$ & $25.4 \pm 3.0$ & $60 \pm 10$ \\
\hline 11. & Nitrothiophene $\mathbf{1 b}$ & -0.280 & 1.70 & $2.2 \pm 0.2 \times 10^{6}$ & $5.4 \pm 0.5 \times 10^{5}$ & $145 \pm 30$ & $20 \pm 5.0$ \\
\hline 12. & Nitrothiophene 1c & -0.260 & 1.26 & $2.8 \pm 0.1 \times 10^{5}$ & $4.0 \pm 0.5 \times 10^{5}$ & $42 \pm 5.0$ & n.d. \\
\hline 13. & Nitrofurantoin & -0.255 & -0.25 & $9.1 \pm 1.4 \times 10^{4}$ & $1.0 \pm 0.2 \times 10^{6}$ & $387 \pm 25$ & $60 \pm 10$ \\
\hline 14. & Nifuroxime & -0.255 & -0.34 & $1.1 \pm 0.1 \times 10^{5}$ & $1.0 \pm 0.1 \times 10^{6}$ & $40 \pm 5.0$ & $70 \pm 10$ \\
\hline 15. & 1,4-Dinitrobenzene & -0.255 & 1.85 & $1.2 \pm 0.1 \times 10^{6}$ & $2.0 \pm 0.2 \times 10^{6}$ & $12.0 \pm 1.5$ & $40 \pm 7.0$ \\
\hline 16. & 2,4,6-Trinitrotoluene & -0.253 & 2.31 & $1.0 \pm 0.1 \times 10^{5}$ & $7.3 \pm 0.2 \times 10^{5}$ & $17.4 \pm 2.0$ & $40 \pm 8.0$ \\
\hline 17. & Nitrofuran 2a & -0.225 & 0.27 & n.d. & $8.7 \pm 0.7 \times 10^{5}$ & $120 \pm 10$ & $65 \pm 5.0$ \\
\hline 18. & Nitrofuran $\mathbf{2 b}$ & -0.225 & 2.64 & $4.0 \pm 0.3 \times 10^{5}$ & n.d. & $3.4 \pm 0,4$ & $2.5 \pm 0.3$ \\
\hline 19. & Nitrofuran $\mathbf{2 e}$ & -0.225 & 2.45 & $7.6 \pm 1.3 \times 10^{5}$ & n.d. & $13.6 \pm 1.5$ & $0.9 \pm 0.2$ \\
\hline 20. & Tetryl & -0.191 & 1.38 & $5.9 \pm 0.2 \times 10^{6}$ & $8.9 \pm 1.0 \times 10^{5}$ & $7.0 \pm 1.0$ & $8.0 \pm 1.5$ \\
\hline
\end{tabular}




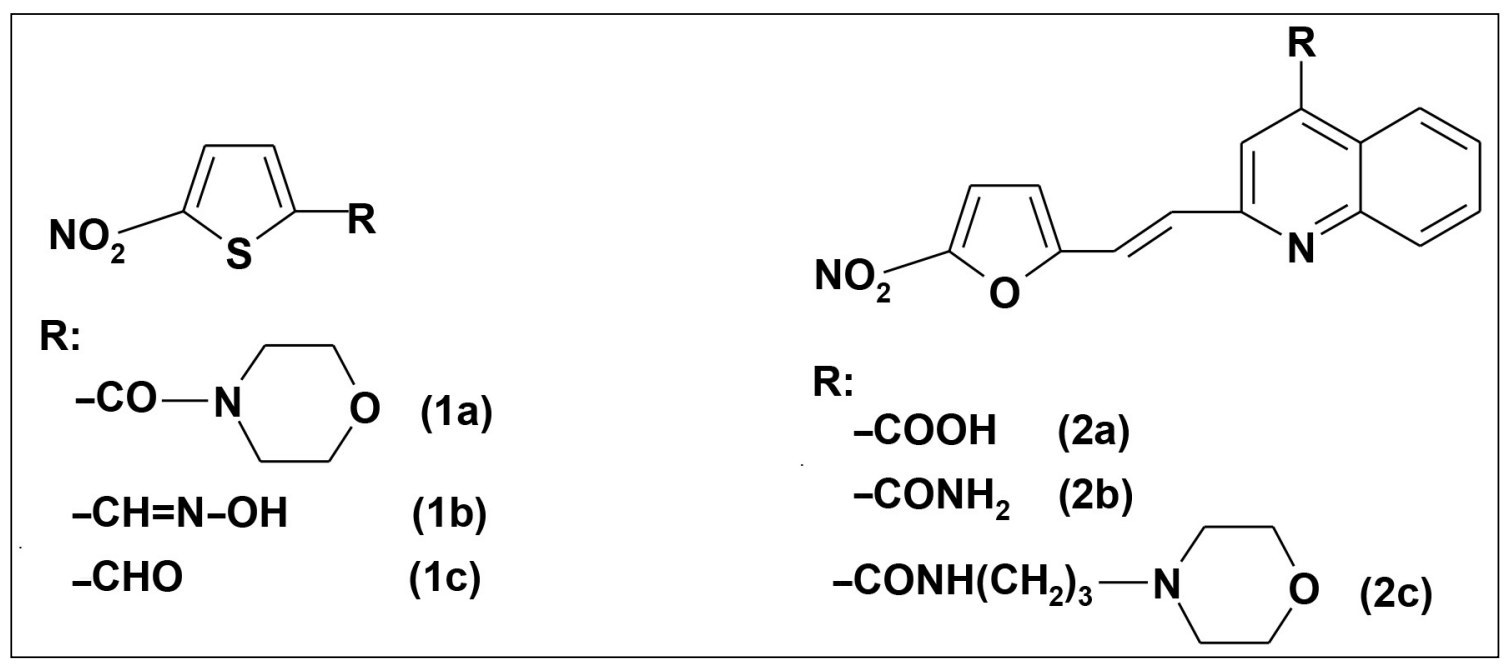

Fig. 1. Formulae of nontrivial nitrothiophenes (1) and nitrofurans (2) used in this work

$\mathrm{ArNO}_{2}$ in the mammalian cell [26]. As an additional model reaction, we studied the reduction of $\mathrm{ArNO}_{2}$ by $\mathrm{Fe}_{2} \mathrm{~S}_{2}$ protein adrenodoxin (ADX). Flavoenzyme NADPH:adrenodoxin reductase (ADR) reduces nitroaromatics very slowly, and ADX stimulates the reaction providing an alternative more efficient electron-transfer pathway via ADX [27]. The bimolecular rate constants $\left(k_{\text {cat }} / K_{\mathrm{m}}\right)$ of reduction of $\mathrm{ArNO}_{2}$ by $\mathrm{P}-450 \mathrm{R}$ and $\mathrm{ADR} / \mathrm{ADX}$ are given in Table 1 . For the most active oxidants of P-450R like tetryl, $p$-dinitrobenzene and nitrofurans (Table 1 ), the $k_{\text {cat }}$ at their saturating concentrations were in a range of 18.0$19.0 \mathrm{~s}^{-1}$, i.e. close to $50 \%$ of the rate of reduction of single-electron acceptor, cytochrome $c$. The $k_{\text {cat }}$ for the same compounds in ADR/ADX-catalyzed reactions were in a range of $3.7-3.3 \mathrm{~s}^{-1}$, which again was close to $50 \%$ of ADX-mediated cytochrome $c$ reduction rate. In other cases, the reaction rates were almost proportional to the concentration of compounds up to the limits of their solubility. The data of Fig. 2a, b show that $\log k_{\text {cat }} / K_{\mathrm{m}}$ of nitroaromatics increase with their $E^{1}{ }_{7}$ values. This may be attributed

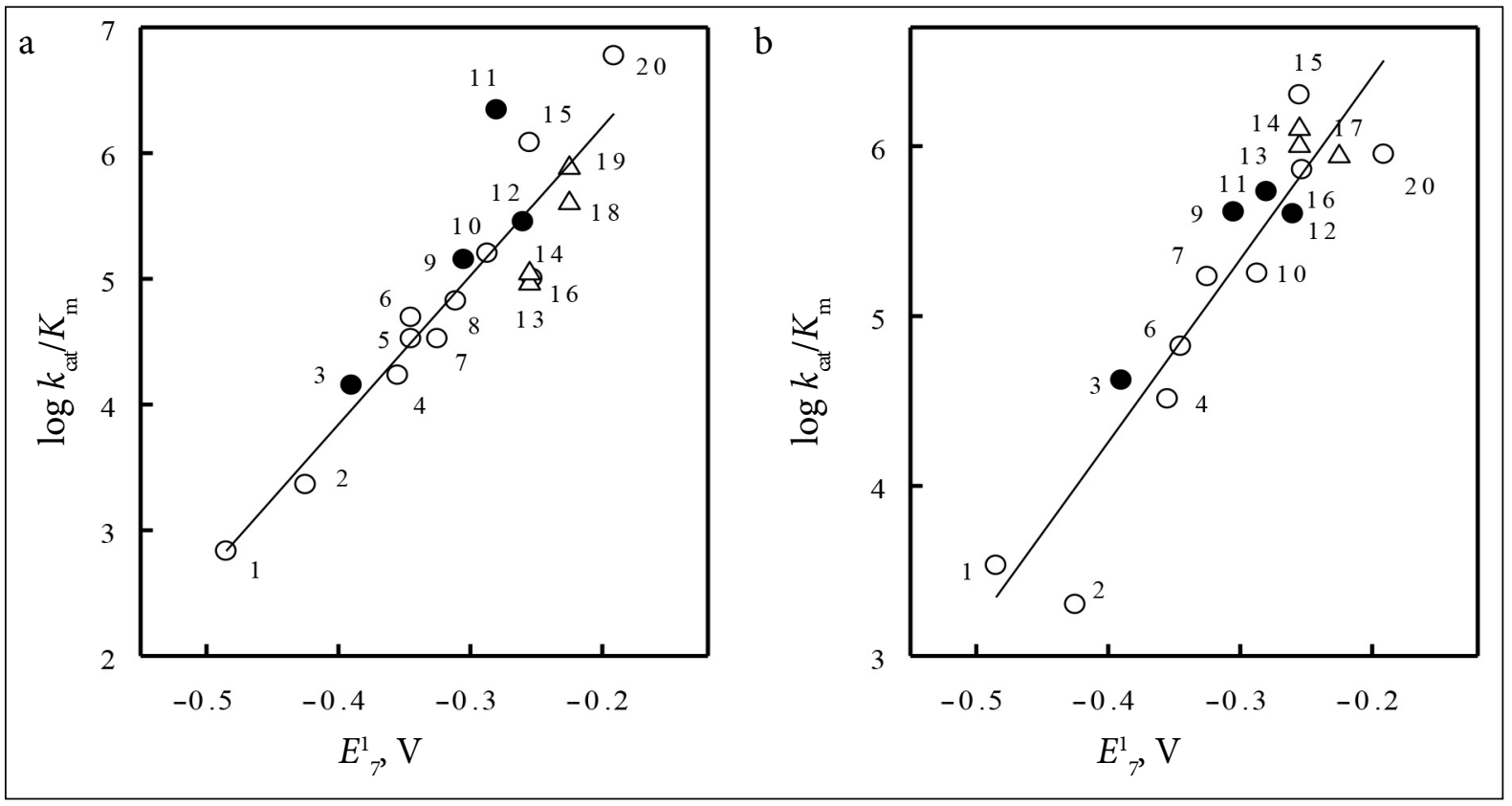

Fig. 2. Dependence of the reactivity $\left(k_{\text {cat }} / K_{\mathrm{m}}\right)$ of nitrobenzenes $(0)$, nitrofurans $(\Delta)$ and nitrothiophenes $(\cdot)$ on their single-electron reduction potential $\left(E_{7}\right)$ in P-450R- (a) and ADR/ADX-catalyzed reactions (b). The numbers of nitroaromatic compounds correspond to those in Table 1 
to an 'outer-sphere' electron transfer mechanism of their reduction with a weak electronic coupling between the reactants and a relative lack of their structure specificity [6, 8].

Typically, NQO1 reduces nitroaromatics with low rates, their reactivity depending on $E_{7}^{1}$ and structural features in an ill-defined way ([15], and references therein). The reactivity of examined nitrobenzenes and nitrofurans was characterized previously [15]. Briefly, mononitrobenzenes and nitrofurans possessed $k_{\text {cat }}=0.05 \div 0.2 \mathrm{~s}^{-1}$ and $k_{\text {cat }} / K_{\mathrm{m}}$ of $25 \div 570 \mathrm{M}^{-1} \mathrm{~s}^{-1}$, dinitrobenzenes and 2,4,6-trinitrotoluene $-k_{\text {cat }}=0.2 \div 1.5 \mathrm{~s}^{-1}$ and $k_{\text {cat }} / K_{\mathrm{m}}=670 \div 1600 \mathrm{M}^{-1} \mathrm{~s}^{-1}$, and tetryl possessed $k_{\text {cat }}=73 \mathrm{~s}^{-1}$ and $k_{\mathrm{cat}} / K_{\mathrm{m}}=2.6 \times 10^{5} \mathrm{M}^{-1} \mathrm{~s}^{-1}$ [15]. In this work, the $k_{\text {cat }}$ and $k_{\text {cat }} / K_{\mathrm{m}}$ of nitrothiophenes were obtained after the correction of NADPH oxidation rates for $340 \mathrm{~nm}$ absorbance changes due to nitrothiophene reduction. It was shown, using the NADPH regeneration system, that the latter did not exceed $15 \%$ total absorbance changes. Their $k_{\text {cat }}$ and $k_{\text {cat }} / K_{\mathrm{m}}$ values were the following: $1.4 \pm 0.1 \mathrm{~s}^{-1}$ and $3.2 \pm 0.2 \times 10^{3} \mathrm{M}^{-1} \mathrm{~s}^{-1}$ (2-nitrothiophene), $\leq 0.1 \mathrm{~s}^{-1}$ at saturating concentration (nitrothiophene 1a), $11.1 \pm 0.7 \mathrm{~s}^{-1}$ and $9.7 \pm 0.8 \times 10^{4} \mathrm{M}^{-1} \mathrm{~s}^{-1}$ (nitrothiophene $1 \mathrm{~b}$ ), and $1.3 \pm 0.2 \mathrm{~s}^{-1}$ and $1.7 \pm 0.2 \times 10^{4} \mathrm{M}^{-1} \mathrm{~s}^{-1}$ (nitrothiophene 1c). Although nitrothiophenes were more reactive than nitrofurans, their reactivity was in line with the generally low nitroreductase activity of NQO1.

In cytotoxicity studies, we determined the $\mathrm{cL}_{50}$ values of nitroaromatics in murine hepatoma MH22a cells, and, for most of them, the concentrations for $50 \%$ of maximal inhibition $\left(\mathrm{GI}_{50}\right)$ of proliferation of human colon adenocarcinoma HCT-116 cells (Table 1). The cytotoxicity of several nitroaromatics in $\mathrm{MH} 22$ a cells was decreased by desferrioxamine and the antioxidant $N, N^{\prime}$-diphenyl-p-phenylene diamine (DPPD), and enhanced by 1,3-bis(2-chloroethyl)-1-nitrosourea (BCNU), the latter inactivating glutathione reductase and depleting reduced glutathione [8, 23] (Table 2). This points to the prooxidant character of their cytotoxicity. In accordance with this, the cytotoxicity of nitroaromatics increased with $E_{7}^{1}$ with the coefficient $\Delta \log \mathrm{cL}_{50} / \Delta E^{1}{ }_{7}=-9.12 \pm 1.47 \mathrm{~V}^{-1}\left(r^{2}=0.683\right)$. This relatively scattered regression was significantly improved by the introduction of compound octanol/water distribution coefficient at $\mathrm{pH} 7.0(\log D$, Table 1):

$$
\begin{aligned}
& \log \mathrm{CL}_{50}=-0.99 \pm 0.32-(8.01 \pm 0.99) E_{7}^{1}- \\
& (0.30 \pm 0.06) \log D, r^{2}=0.878
\end{aligned}
$$

$\mathrm{GI}_{50}$ of nitroaromatics in HCT-116 cells also decreased with their $E_{7}^{1}\left(\Delta \log \mathrm{GI}_{50} / \Delta E^{1}{ }_{7}=-11.88 \pm\right.$ $\left.1.74 \mathrm{~V}^{-1}, r^{2}=0.756\right)$. Again, the introduction of $\log$ $D$ ignificantly improved the regression:

$$
\begin{aligned}
& \log \mathrm{cL}_{50}=-0.84 \pm 0.10-(10.40 \pm 1.21) E_{7}^{1}- \\
& (0.31 \pm 0.07) \log D, r^{2}=0.898
\end{aligned}
$$

Concerning the other enzymatic mechanisms possibly affecting the cytotoxicity of $\mathrm{ArNO}_{2}$, we examined the effects of an inhibitor of NQO1, dicoumarol, and several inhibitors of cytochromes P-450 on the cytotoxicity of several randomly chosen compounds in MH22a cells (Table 3). In most cases, with a notable exception of tetryl and partly $p$-dinitrobenzene, the inhibitors decreased the cytotoxicity of $\mathrm{ArNO}_{2}$ (Table 3). Interestingly, although cytochrome P-450-catalyzed oxidative denitration of nitrofurantoin in the cell-free system is most thoroughly documented [17], its inhibitors did not affect the cytotoxicity of nitrofurantoin in MH22a cells (data not shown).

Table 2. Modulation of the cytotoxicity of nitroaromatic compounds in MH22a cells by $N . N^{\prime}$-diphenyl-p-phenylene diamine (DPPD), desferrioxamine (DESF) and 1,3-bis(2-chloroethyl)-1-nitrosourea (BCNU), $n=3, p<0.02 *$

\begin{tabular}{c|c|c|c|c}
\hline \multirow{2}{*}{ Compound } & \multicolumn{4}{|c}{ Cell viability, \% } \\
\cline { 2 - 5 } & \multirow{2}{*}{ No additions } & \multicolumn{3}{|c}{ Additions: } \\
\cline { 3 - 5 } & & DPPD $(\mathbf{2 . 0} \mu \mathrm{M})^{*}$ & DESF (1.0 mM)* & BCNU (20 $\boldsymbol{\mu M})^{*}$ \\
\hline$p$-Dinitrobenzene $(12 \mu \mathrm{M})$ & $50.5 \pm 2.5$ & $70.2 \pm 5.2$ & $75.3 \pm 4.0$ & $34.8 \pm 2.7$ \\
\hline $2,4,6$-Trinitrotoluene $(35 \mu \mathrm{M})$ & $35.8 \pm 3.6$ & $52.8 \pm 5.0$ & $55.3 \pm 5.9$ & $24.0 \pm 2.7$ \\
\hline Tetryl $(15 \mu \mathrm{M})$ & $37.1 \pm 3.4$ & $63.8 \pm 4.7$ & $65.7 \pm 4.1$ & $23.5 \pm 3.2$ \\
\hline
\end{tabular}


Ta ble 3. Modulation of the cytotoxicity of nitroaromatic compounds in MH22a cells by dicoumarol (DIC), a-naphthoflavone (a-NF), isoniazid (ISO) and miconazole (MIC), $n=3, p<0.05^{*}, p<0.02^{* *}, p<0.01^{* * *}$

\begin{tabular}{|c|c|c|c|c|c|}
\hline \multirow{3}{*}{ Compound } & \multicolumn{5}{|c|}{ Cell viability, \% } \\
\hline & \multirow{2}{*}{ No additions } & \multicolumn{4}{|c|}{ Additions: } \\
\hline & & DIC $(20 \mu \mathrm{M})$ & $a-N F(5.0 \mu M)$ & ISO (1.0 mM) & MIC (5.0 $\mu \mathrm{M})$ \\
\hline Nifuroxime $(60 \mu \mathrm{M})$ & $37.0 \pm 2.5$ & $62.2 \pm 8.2^{* *}$ & $66.7 \pm 9.3^{* *}$ & $75.1 \pm 7.3^{* * *}$ & $61.3 \pm 5.3^{* *}$ \\
\hline Nitrofuran 3e $(25 \mu \mathrm{M})$ & $37.9 \pm 4.2$ & $49.7 \pm 4.2^{*}$ & $55.0 \pm 4.9^{* *}$ & $46.8 \pm 4.2$ & $49.8 \pm 3.4^{*}$ \\
\hline Nitrothiophene $(150 \mu \mathrm{M})$ & $51.5 \pm 3.4$ & $71.1 \pm 1.6^{* *}$ & $74.5 \pm 3.8^{* *}$ & $71.5 \pm 4.2^{* *}$ & $77.8 \pm 2.6^{* *}$ \\
\hline$p$-Dinitrobenzene $(18 \mu \mathrm{M})$ & $34.2 \pm 1.0$ & $19.3 \pm 5.9^{* *}$ & $52.4 \pm 6.3^{* *}$ & $53.8 \pm 6.8^{* *}$ & $62.7 \pm 10.7^{* *}$ \\
\hline 2,4,6-Trinitrotoluene $(18 \mu \mathrm{M})$ & $46.6 \pm 5.2$ & $44.7 \pm 4.0$ & $81.2 \pm 4.2^{* * *}$ & $68.7 \pm 3.1^{* *}$ & $67.2 \pm 3.5^{* *}$ \\
\hline Tetryl $(7.0 \mu \mathrm{M})$ & $54.0 \pm 5.6$ & $33.9 \pm 3.3^{* *}$ & $65.7 \pm 5.9$ & $64.6 \pm 4.3$ & $29.0 \pm 1.3^{* * *}$ \\
\hline
\end{tabular}

\section{DISCUSSION}

Redox cycling is an intrinsic property of $\mathrm{ArNO}_{2}$, being an important factor and a prognostic criterion for efficacy-to-safety ratio of existing and new nitroaromatic drugs [28]. In our opinion, the deviation from the limits predicted by the redox cycling activity could be instrumental in the characterization of additional mechanisms of cytotoxicity or therapeutic action of nitroaromatics.

Our data (Fig. 2a, b) demonstrate linear $\log k_{\text {cat }} /$ $K_{\mathrm{m}}$ vs $E^{1}{ }_{7}$ dependences, which are typical of single-electron enzymatic reduction of $\mathrm{ArNO}_{2}$ [6, 8]. They point to the absence of pronounced substrate specificity, including the previously uncharacterized oxidants, nitrothiophenes. In turn, the linear $\log \mathrm{cL}_{50}\left(\mathrm{GI}_{50}\right)$ vs $E_{7}^{1}$ relationships (Fig. 3a, b) taken together with the data on the antioxidant protection (Table 2 ) point to the predominantly prooxidant character of $\mathrm{ArNO}_{2}$ cytotoxicity. The coefficients $\Delta \log \mathrm{cL}_{50} / \Delta E_{7}^{1}$ in Eqs. 1 and 2 were similar to those obtained previously in V79 Chinese hamster cells, $-8.37 \pm 0.89 \mathrm{~V}^{-1}$ ([4], $168 \mathrm{~h}$ incubation), and FLK lamb kidney fibroblasts, $-10.74 \pm 1.19 \mathrm{~V}^{-1}$ ([8], $24 \mathrm{~h})$. Importantly, the noticeable differences do not exist between the efficacy of nitrobenzenes, nitrofurans and nitrothiophenes (Fig. 3a, b). This fact rules out the manifestation of an additional

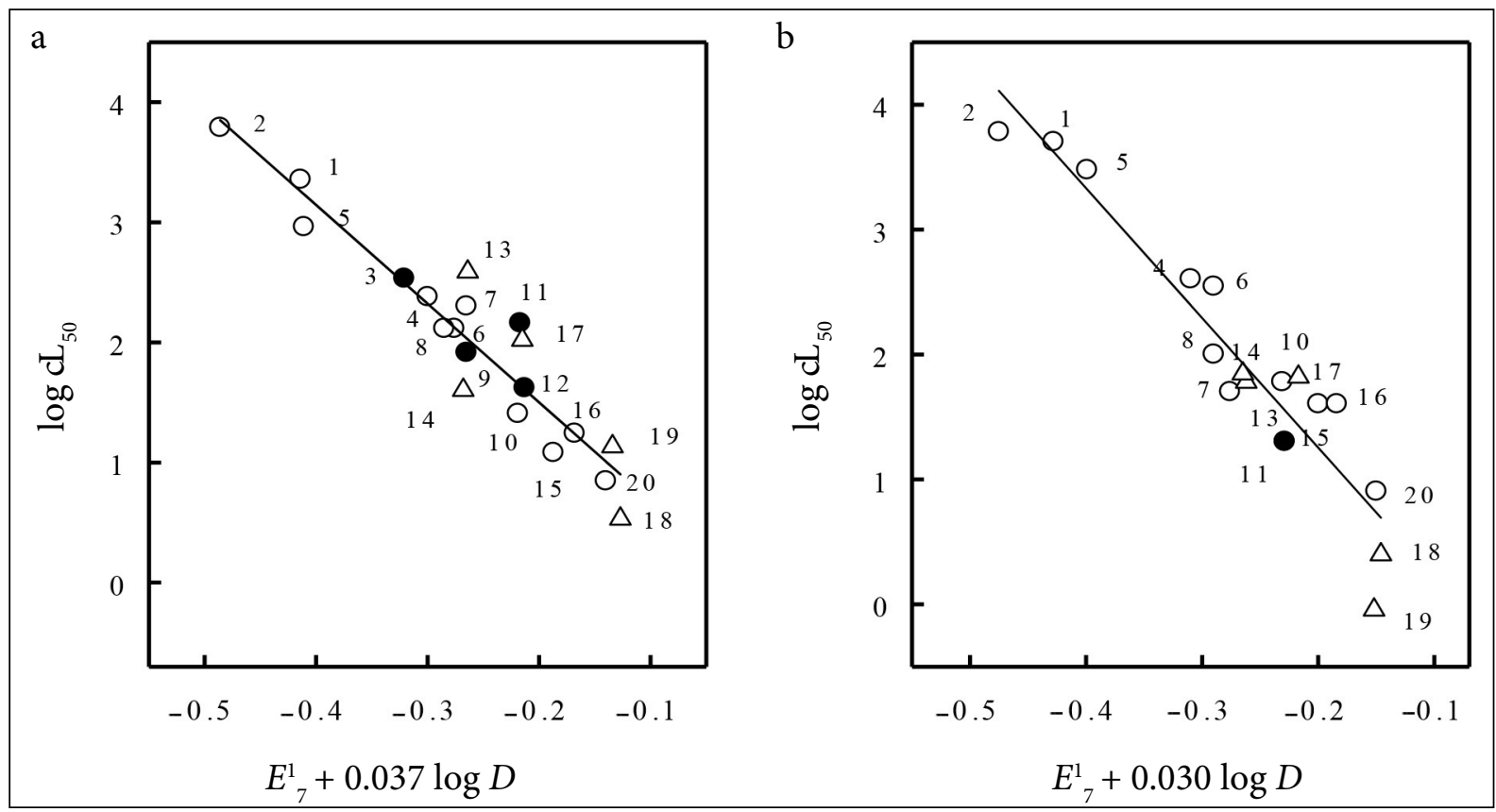

Fig. 3. Dependence of cytotoxicity $\left(\mathrm{CL}_{50}\right)$ or proliferation inhibition potency $\left(\mathrm{Gl}_{50}\right)$ of nitrobenzenes $(0)$, nitrofurans $(\Delta)$ and nitrothiophenes $(\cdot)$ on their single-electron reduction potential $\left(E_{7}^{1}\right)$ and lipophilicity $(\log D)$ in MH22a (a) and HCT-116 cells (b) according to Eqs. 1 (a) and 2 (b). The numbers of nitroaromatic compounds correspond to those in Table 1 
mechanism of cytotoxicity of nitrofurans, the formation of unsaturated open-chain nitriles [29]. However, our study clarifies the roles of several additional factors that modulate the prooxidant $c y-$ totoxicity of $\mathrm{ArNO}_{2}$, which will be analysed below.

According to previous findings, the effects of lipophilicity were not evident in the action of $\mathrm{ArNO}_{2}$ in primary rat hepatocytes [5] and primary mice splenocytes [13]. In V79 cells, this effect is poorly expressed, $\Delta \log \mathrm{CL}_{50} / \Delta \log P=-0.14 \pm 0.09$ [4], where $\log P$ is an octanol/water partition coefficient. On the other hand, our data on the positive impact of $\log D$ on the cytotoxicity of nitroaromatics in two cell lines (Eqs. 1,2) were close to those observed in FLK cells, $\Delta \log \mathrm{cL}_{50} / \Delta \log$ $P=-0.21 \pm 0.08$ [8], and L6 rat myoblasts, $\Delta \log$ $\mathrm{CL}_{50} / \Delta \log P=-0.388$ ([18], $72 \mathrm{~h}$ ).

Evidently, the impact of $\mathrm{ArNO}_{2}$ lipophilicity may depend on the cell type and experimental conditions, however, it should be taken into account in the analysis of QSARs of nitroaromatics.

NQO1 reduces $\mathrm{ArNO}_{2}$ into DNA-alkylating hydroxylamines ([14], and references therein), therefore, it should contribute to their cytotoxicity. The reasons for an unexpected enhancement of cytotoxicity of tetryl and $p$-dinitrobenzene by dicoumarol (Table 3 ) are unclear, except the possible conversion of tetryl into less toxic $\mathrm{N}$-methylpicramide by NQO1 [8]. The same effects were observed in FLK cells [8]. Interestingly, dicoumarol similarly affects the cytotoxicity of both weak and relatively active substrates of NQO1 (Tables 1, 3).

Cytochromes P-450 catalyze the denitration of heterocyclic compounds, nitrofurantoin and 5-nitro-1,2,4-triazol-3-one, with the formation of corresponding hydroxy derivatives $[16,17]$. The reaction intermediate, epoxide, reacts with thiol groups [17]. In our opinion, depending on the nature of the compound, this may either contribute to their toxicity (reactions with -SH groups of particular enzymes), either to detoxification (reaction with reduced glutathione). The data of Table 3 show that cytochromes P-450 are involved in the cytotoxicity of several nitrobenzenes as well. Currently, the data on their oxidative denitration are unavailable, thus, an alternative or parallel cytotoxicity mechanism could be the preventing of formation of amine products of polinitrobenzene reduction by their $\mathrm{N}$-hydroxylation with formation of hydroxylamines [30].

\section{CONCLUSIONS}

A general conclusion based on current and previous studies is that in different mammalian cells and under different conditions, the aerobic cytotoxicity of nitroaromatics, which do not possess additional reactive substituents, similarly depends on their $E^{1}{ }_{7}$ values. The dependence of cytotoxicity on compound lipophilicity may be more sensitive to the cell type and experimental conditions. These two factors may be important for the prediction of side-effects or estimation of therapeutic mechanisms of nitroaromatics. This study also shows that NQO1 and cytochromes P-450 exert equivocal effects on $\mathrm{ArNO}_{2}$ cytotoxicity, which evidently do not significantly affect the observed QSARs. The elucidation of the roles of these enzymes warrants further studies.

\section{ACKNOWLEDGEMENTS}

This work was supported by the European Social Fund (Measure No. 09.33-LMT-K-712, Grant No. DOTSUT-34/09.3.3.-LMT-K712-01-0058/LSS600000-58).

Received 8 May 2020 Accepted 19 May 2020

\section{References}

1. D. E. Rickert, Drug Metab. Rev., 18, 23 (1987).

2. V. Purohit, A. K. Basu, Chem. Res. Toxicol., 13, 673 (2000).

3. P. Kovacic, R. Somanathan, J. Appl. Toxicol., 34, 810 (2014).

4. G. E. Adams, E. D. Clarke, P. Gray, et al., Int. J. Radiat. Biol., 35, 151 (1979).

5. P. J. O’Brien, W. C. Wong, J. Silva, S. Khan, Xenobiotica, 20, 945 (1990).

6. R. P. Mason, Environ. Health Persp., 87, 237 (1990).

7. V. Miškinienė, E. Sergedienè, A. Nemeikaite, et al., Cancer Lett., 146, 217 (1999).

8. N. Čènas, A. Nemeikaitè-Čènienè, E. Sergedienè, et al., Biochim. Biophys. Acta, 1528, 31 (2001).

9. P. Wardman, M. F. Dennis, S. A. Everett, et al., Biochem. Soc. Symp., 61, 171 (1995).

10. J. M. Walling, I. J. Stratford, G. E. Adams, Int. J. Radiat. Biol., 52, 31 (1987).

11. J. Šarlauskas, E. Dičkancaitè, A. Nemeikaitè, et al., Arch. Biochem. Biophys., 346, 219 (1997).

12. J. Pourahmad, S. Khan, P. J. O’Brien, Adv. Exp. Med. Biol., 500, 261 (2001). 
13. V. Miliukienè, N. Čènas, Z. Naturforsch., 63c, 519 (2008).

14. R. J. Knox, P. J. Burke, S. Chen, D. J. Kerr, Curr. Pharm. Des., 9, 2091 (2003).

15. L. Misevičiene, Ž. Anusevičius, J. Šarlauskas, N. Čènas, Acta Biochim. Pol., 53, 569 (2006).

16. L. Le Campion, M. Delaforge, J. P. Noel, J. Ouazzani, Eur. J. Biochem., 248, 401 (1997).

17. H. Li, D. Lin, Y. Peng, J. Zheng, Xenobiotica, 47, 103 (2017).

18. M. V. Papadopolou, W. D. Bloomer, H. S. Rosenzweig, et al., Eur. J. Med. Chem., 117, 179 (2016).

19. T. A. Pechurskaja, I. N. Hornastai, I. P. Grabovec, et al., Biochem. Biophys. Res. Comm., 353, 598 (2007).

20. H. J. Prochaska, Arch. Biochem. Biophys., 267, 529 (1988).

21. A. Breccia, F. Busi, E. Gattavechia, M. Tamba, Radiat. Environ. Biophys., 29, 153 (1990).

22. E. Lukevits, T. V. Lapina, N. M. Sukhova, et al., Pharm. Chem. J., 15, 792 (1981).

23. A. Nemeikaitè-Čènienè, J. Šarlauskas, V. Jonušienè, et al., Int. J. Molec. Sci., 20, 4602 (2019).

24. P. Wardman, J. Phys. Chem. Ref. Data, 18, 1637 (1989).

25. A. Marozienè, M. Lesanavičius, E. DavioudCharvet, et al., Molecules, 24, 4509 (2019).

26. U. A. Boelsterli, H. K. Ho, S. Zhou, K. Y. Leow, Curr. Drug Metab., 7, 715 (2006).

27. J. Marcinkevičienè, N. Čènas, J. Kulys, et al., Biomed. Biochim. Acta, 49, 167 (1990).

28. K. Nepali, H.-Y. Lee, J.-P. Liou, J. Med. Chem., 62, 2851 (2019).

29. C. Bot, B. S. Hall, G. Alvarez, et al., Antimicrob. Agents Chemother., 57, 1638 (2013).

30. M. Ohbushi, M. Miyata, D. Nagai, et al., Drug Metab. Disp., 25, 1298 (2009).
Aušra Nemeikaitè-Čènienè, Jonas Šarlauskas,

Violeta Jonušienè, Lina Misevičienė,

Audronė Marozienė, Aliaksei V. Yantsevich, Narimantas Čènas

\section{NITROAROMATINIU JUNGINIU \\ PROOKSIDACINIO CITOTOKSIŠKUMO \\ ŽINDUOLIŲ LĄSTELĖSE QSAR: JUNGINIŲ \\ LIPOFILIŠKUMO IR CITOCHROMŲ P-450 BEI \\ DT-DIAFORAZĖS KATALIZUOJAMŲ REAKCIJŲ VAIDMUO}

Santrauka

Nitroaromatinių junginių $\left(\mathrm{ArNO}_{2}\right)$ citotoksiškumas žinduolių ląstelèse aerobinèmis sąlygomis dažnai didejja augant jų vienelektroninès redukcijos potencialui $\left(E_{7}^{1}\right)$, taip atsispindi ryšys tarp jų $E^{1}$ ir vienelektroninès redukcijos fermentais greičio. Pagrindinis $\mathrm{ArNO}_{2}$ citotoksiškumo veiksnys yra cikliniai redokso virsmai ir oksidacinis stresas. Nustateme, kad eilès nitrobenzene, nitrofuranų ir nitrotiofenų reakcingumas vieną elektroną pernešančiu NADPH:cytochromo P-450 reduktazès ir adrenodoksino reduktazès / adrenodoksino atžvilgiu dideja, didèjant jų $E_{7}^{1}$. Tačiau jų citotoksiškumas pelès hepatomos MH22a ir žmogaus gaubtinès žarnos karcinomos HCT-116 ląstelèse prastai koreliavo su $E^{1}$. Koreliacijos pageredavo antru kintamuoju naudojant junginio oktanolio / vandens pasiskirstymo koeficientą prie pH 7,0 $(\log D)$. Tai rodo, kad $\mathrm{ArNO}_{2}$ lipofiliškumas didina jų citotoksiškumą. Citochromų P-450 inhibitoriai $\alpha$-naftoflavonas, izoniazidas ir mikonazolas, taip pat DT-diaforazès inhibitorius dikumarolas dažniausiai didindavo kai kurių atsitiktinai parinktų junginių citotoksiškumą. Stebimos citotoksiškumo priklausomybès nuo $E_{7}^{1}$ faktiškai atspindi kelių citotoksiškumo mechanizmų atstojamąsias. 